\title{
AN EXTENSION OF SPECHT'S THEOREM \\ VIA KANTOROVICH INEQUALITY \\ AND RELATED RESULTS
}

\author{
TAKEAKI YAMAZAKI
}

Abstract. In this paper, we shall show the following result.

"If $M I \geqslant A \geqslant m I>0$ with $M>m>0$, then

$$
K_{+}\left(m^{r}, M^{r}, \frac{p}{r}\right)^{\frac{1}{p}}\left(A^{r} x, x\right)^{\frac{1}{r}} \geqslant\left(A^{p} x, x\right)^{\frac{1}{p}}
$$

for $p>r>0$, where

$$
K_{+}(m, M, p)=\frac{(p-1)^{p-1}}{p^{p}} \frac{\left(M^{p}-m^{p}\right)^{p}}{(M-m)\left(m M^{p}-M m^{p}\right)^{p-1}} . ”
$$

This result is an extension of Specht's theorem [6] as a converse of the arithmetic-geometric mean inequality.

"If $x_{1}, x_{2}, \cdots, x_{n} \in[m, M]$ with $M>m>0$, then

$$
M_{h} \sqrt[n]{x_{1} x_{2} \cdots x_{n}} \geqslant \frac{x_{1}+x_{2}+\cdots+x_{n}}{n}
$$

where $h=\frac{M}{m}>1$ and $M_{h}=\frac{h^{\frac{1}{h-1}}}{e \log h^{\frac{1}{h-1}}}$."

Secondly, we shall show an application for operator inequalities, that is, "if $A \geqslant B \geqslant 0$ satisfying $M I \geqslant B \geqslant m I>0$ with $M>m>0$, then

$$
A^{p}-B^{p} \geqslant \frac{-\left(m M^{p}-M m^{p}\right)}{M-m}\left\{K_{+}(m, M, p)^{\frac{1}{p-1}}-1\right\}
$$

for $p>1$.”

Mathematics subject classification (1991): 47A30, 47A63.

Key words and phrases: Kantorovich inequality, positive operator, Specht's ratio.

\section{REFERENCES}

[1] J. I. FuJII, T. FuRUtA, T. YAMAZAKI AND M. YANAGIDA, Simplified proof of characterization of chaotic order via Specht's ratio, Scientiae Mathematicae, 2 (1999), 63-64.

[2] J. I. FuJII, S. IZUMINO AND Y. SEO, Determinant for positive operators and Speht's theorem, Scientiae Mathematicae, 1 (1998), 307-310.

[3] J. I. FuJII AND Y. SEO, Determinant for positive operators, Scientiae Mathematicae, 1 (1998), 153-156.

[4] T. FURUTA, Operator inequalities associated with Hölder-McCarthy and Kantorovich inequalities, J. Inequal. Appl., 2 (1998), 137-148.

[5] J. Mićić, Y. SEO, S-E. TAKAHASHI AND M. Tominaga, Inequalities of Furuta and Mond-Pečarić, Math. Ineq. Appl., 2 (1999), 83-111.

[6] W. SPECHT, Zur Theorie der elementaren Mittel, Math. Z., 74 (1960), 91-98.

[7] T. YAMAZAKI AND M. YANAGIDA, Characterizations of chaotic order associated with Kantorovich inequality, Scientiae Mathematicae, 2 (1999), 37-50. 